\title{
$\mathrm{AIA}$ 및 $\mathrm{CMAA}$ 의 $\mathrm{CM}$ 분석을 통한 국내 $\mathrm{CM}$ 적용 시안
}

\section{A Domestic Application of CM System through a Comparative Analysis of AIA and CMAA CM Roles}

\section{박 종 혁*}

Park, Jong Hyuk,
박 홍 태**

Park, Hong Tae

\section{Abstract}

This study tries to provide concept on establishment of $\mathrm{CM}$ license basis, $\mathrm{CM}$ selection procedure and $\mathrm{CM}$ contract documents through a comparative study of CM services in several CM contract documents in the America. This results of study are summarized as follows ; Establishment of basis on the work scopes and legal license of $\mathrm{CM}$ company. Establishment of $\mathrm{CM}$ selection and contract procedure. Preparation of CM contract documents. Preparation of CM manual.

키워드 : 계 약절차, 계 약문서, 자격기준, 전설사업관리

Keywords : Contract Procedure. Contract Documents. License Basis, Construction Management

\section{1. 서 론}

\section{1 연구의 배경 및 목적}

국내의 건설사업관리(CM ; Construction Management 『이하 $\mathrm{CM}_{\lrcorner}$)제도는 필요에 의해서 생성된 구미와는 부실공사 방지 및 국제경쟁력 강화라는 목표아래 보다 효율적이며 혁신적인 건설사업의 수행을 위해 도입 검토되기 시작하였다. 이후 활발 한 토의와 연구를 통하여 1997년 건설산업기본법에서 건설사 업관리를 하나의 업역으로 제정하게 되었으며, 건설사업관리 협회의 창설 등 적극적인 $\mathrm{CM}$ 도입을 추진해왔다. 그러나 건설 산업기본법에서는 $\mathrm{CM}$ 에 대한 정의와 간략한 업역 만을 규정 해 놓았을 뿐 그 밖의 세부규칙이나 시행기준, 관련문서 둥이 정립되지 않아 건설사업 수행방식으로서의 $\mathrm{CM}$ 에 대하여 건설 사업 참여자 간에 큰 혼란이 야기되고 있다. 기존 업역 간의 대 립, $\mathrm{CM}$ 존재 유무의 논쟁, 신체계에 대한 보수 등이 이러한 혼 란에서 야기된 것이라 할 수 있다.

국내 $\mathrm{CM}$ 의 경우 이러한 문제를 해결하기 위해서는 법적, 제도적인 환경 설정이 선행되어야 하며, 현시점에서 발주자가 $\mathrm{CM}$ 의 개념을 정확히 파악하고 건설공사에 $\mathrm{CM}$ 의 필요성을 인 식하여 능동적으로 $\mathrm{CM}$ 체계를 활용할 수 있는 기반을 구축해 놓아야 $\mathrm{CM}$ 이 보다 활성화 될 것으로 사료된다.

1) 따라서 본 연구에서는 $\mathrm{CM}$ for Fee방식을 중심으로 $\mathrm{CM}$ 의 특징과 활용방식, 미국의 $\mathrm{CM}$ 관련기관에서 제시하는 $\mathrm{CM}$ 역할 을 비교 분석하고, 국내 $\mathrm{CM}$ 활용의 문제점을 파악하여 제도적 으로 정착해야 할 우선 과제를 설정함으로써 이에 대한 개념적 시안을 제시하는데 그 목적이 있다.

* 정회원, 서일대학 토목공학과 교수, 공학박사

** 정회원, 공주대학교 건설환경공학부 교수, 공학박사, 교신저자

\section{2 연구의 방법 및 절차}

본 연구는 $\mathrm{CM}$ 의 정의와 $\mathrm{CM}$ 계야체계의 유형을 살펴보고 $\mathrm{CM}$ for Fee방식을 중심으로 공사단계별 $\mathrm{AIA}$ 및 $\mathrm{CMAA}$ 의 $\mathrm{CM}$ 계약도서체계를 비교 분석한다. 그리고 국내 $\mathrm{CM}$ 제도의 문제점 을 파악한 후, 제도적으로 정착화 되어야할 과제를 제시한다. 이상의 연구방법과 절차를 그림으로 나타내면 그림 1 과 같다.

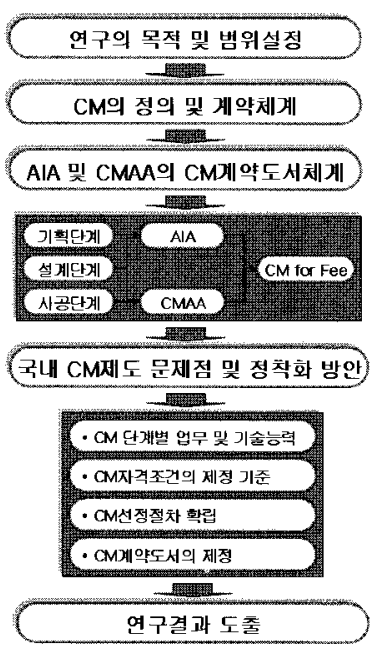

그림 1. 연구의 방법 및 절차

\section{2. $\mathrm{CM}$ 의 정의 및 계약체계}

\subsection{AIA 및 CMAA의 $\mathrm{CM}$ 정의}

미국건축사협회(The American Institute of Architects ; AIA) 
에서 제시하는 $\mathrm{CM}$ 이라 함은 “설계, 시공 또는 이 두 단계에 서 필요한 경험을 소유한 개인이나 단체가 공사 발주자에게 제 공하는 것이다. 이러한 $\mathrm{CM}$ 용역은 설계와 시공의 공기 및 비용 의 결정, 일정수립, 비용통제, 계약의 협상 및 체결의 조정, 긴 급자재구매, 시공활동의 조정에 대한 조언 등을 제공하게 된 다" 라고 정의하고 있으며, 미국 $\mathrm{CM}$ 협회(The Construction Management Association of America ; $\mathrm{CMAA}$ )에서 제시하는 $\mathrm{CM}$ 이라 함은 “공정관리, 원가관리, 품질관리, 안전관리, 환경 관리의 공사목적을 위해 공사의 착수부터 종료까지 적용되는 전문적 관리의 일련의 과정" 이라 정의하고 있다.

\section{$2.2 \mathrm{CM}$ 계약체계의 분류}

$\mathrm{CM}$ 의 계약체계는 공사의 종류와 발주자의 제공조건에 따라 달라진다. 계약자간 업무할당에는 여러 가지 선택방법이 있으 며, 그에 따라 많은 계약유형이 발생하게 된다. 이러한 계약체 결의 유연성 및 융통성으로 발주자는 공사의 조건에 적절한 유 형으로 계약을 선택하여 체결할 수 있다. 다음 표 1 은 $\mathrm{CM}$ 계 약유형에 따른 $\mathrm{CM}$ 의 역할 및 관계를 보이고 있다.

표 1. 계약의 유형에 따른 $\mathrm{CM}$ 의 역할 및 관계

\begin{tabular}{|c|c|c|c|}
\hline \multicolumn{2}{|c|}{ 계약유형 } & $\mathrm{CM}$ 의 역할 및 관계 & 분류 \\
\hline \multicolumn{2}{|c|}{ 대리형 CM } & $\begin{array}{l}\text { - 발주자에 대한 대리인, 조언자 } \\
\text { 역할 }\end{array}$ & $\mathrm{CM}$ for Fee \\
\hline \multirow{4}{*}{$\begin{array}{l}\text { 확장형 } \\
\mathrm{CM}\end{array}$} & 설계형 & - 설계업무와 $\mathrm{CM}$ 업무의 결합형태 & $\mathrm{CM}$ for Fee \\
\hline & 계약형 & - $\mathrm{CM}$ 이 시공자와 계약관계 & $\mathrm{CM}$ at Risk \\
\hline & 시공형 & $\begin{array}{l}\text { - } \mathrm{CM} \text { 이 일부 공사에 직접 참여하 } \\
\text { 는 형태 }\end{array}$ & $\mathrm{CM}$ at Risk \\
\hline & $\begin{array}{c}\text { 계약 및 } \\
\text { 시공형 }\end{array}$ & - 계약과 시공의 복합형태 & CM at Risk \\
\hline \multirow{4}{*}{$\begin{array}{l}\text { 최대공사 } \\
\text { 비 보증형 } \\
\text { CM } \\
\text { (GMP-CM) }\end{array}$} & 기본형 & $\begin{array}{l}\text { - 대리형 } \mathrm{CM} \text { 형태에 최대공사비 } \\
\text { 보증형 계약체결 }\end{array}$ & CM at Risk \\
\hline & 계약형 & $\begin{array}{l}\text { - } \mathrm{CM} \text { 이 시공자와 계약관계 } \\
\text { - 발주자와 최대공사비 보증형 } \\
\text { 체결 }\end{array}$ & $\mathrm{CM}$ for Fee \\
\hline & 시공형 & $\begin{array}{l}\text { - } \mathrm{CM} \text { 이 일부공사에 직접 참여 } \\
\text { - 발주자와 최대공사비 보증형 } \\
\text { 체결 }\end{array}$ & CM at Risk \\
\hline & $\begin{array}{l}\text { 계약 및 } \\
\text { 시공형 }\end{array}$ & $\begin{array}{l}\text { - 계약과 시공의 복합형태 } \\
\text { - 발주자와 최대공사비 보증형 } \\
\text { 체결 }\end{array}$ & CM at Risk \\
\hline
\end{tabular}

주) GMP-CM : Guaranted Maximum Price - $\mathrm{CM}$

\section{3. $\mathrm{AIA}$ 및 $\mathrm{CMAA}$ 의 $\mathrm{CM}$ 계약도서체계}

\section{$3.1 \mathrm{CM}$ 표준계약서의 구성}

$\mathrm{AIA}$ 에서는 $\mathrm{CM}$ 의 방식을 대리인 및 조언자 역할을 수행하 는 $\mathrm{CM}$ for Fee방식과 대리인 역할 뿐만 아니라 시공자 역할까 지 수행하는 $\mathrm{CM}$ at Risk로 나누어 표준계약서를 제시하고 있 다. $\mathrm{CMAA}$ 에서는 $\mathrm{CM}$ for Fee방식과 $\mathrm{CM}$ at Risk방식에 따라 표준계약서를 제시하고 있으며, 기타 공사참여자들도 $\mathrm{CM}$ 계약 의 유형에 맞추어 작성된 표준계약서를 사용하도록 규정하고
있다. 표 2는 기관별 표준계약서를 보이고 있으며, 표 3 및 표 4는 AIA와 CMAA에서 제시하고 있는 표준계약서의 구성을 보 이고 있다. $\mathrm{CM}$ for Fee방식의 경우 $\mathrm{AIA}$ 표준계약서와 $\mathrm{CMAA}$ 표준계약서의 구성을 살펴보면, 구성의 체계는 다소 달리하고 있지만, 두 기관의 업무내옹은 대동소이함을 나타내고 있다.

표 2. $\mathrm{CM}$ 계약시 기관별 표준계약서의 비교

\begin{tabular}{|c|c|c|c|c|}
\hline \multirow{2}{*}{ 구분 } & \multicolumn{2}{|c|}{ AlA } & \multicolumn{2}{|c|}{ CMAA } \\
\hline & $\mathrm{CM}$ for Fee & $\mathrm{CM}$ at Risk & $\mathrm{CM}$ for Fee & $\mathrm{CM}$ at Risk \\
\hline $\begin{array}{l}\text { 발 주 자 } \\
\text { - } \mathrm{CM}\end{array}$ & $\begin{array}{l}\text { AlA Doc. } \\
\text { B801/CMa }\end{array}$ & $\begin{array}{l}\text { - 최대 공사비 } \\
\frac{\text { 보증형(GMP) }}{\text { 방식 }} \\
\text { AIA Doc. } \\
\text { A121/CMc \& AGC } \\
565 \\
\frac{\text { Cost plus fee }}{\text { 방식 }} \\
\text { AIA Doc. } \\
\text { A131/CMc \& AGC } \\
566\end{array}$ & $\begin{array}{c}\text { CMAA Doc. No. } \\
\text { A-1 }\end{array}$ & $\begin{array}{c}\text { CMAA Doc. No. } \\
\text { GMP-1 }\end{array}$ \\
\hline
\end{tabular}

$\mathrm{AGC}$ (The Associated General Contractor of America, 미국건설업협회) : $\mathrm{CM}$ at Risk방식의 경우 $\mathrm{AIA}$ 와 병행 사용

$\mathrm{CMa}$ : CM-Agent, $\mathrm{CMc}$ : CM-Constructor

표 3. AIA 표준계약서의 구성

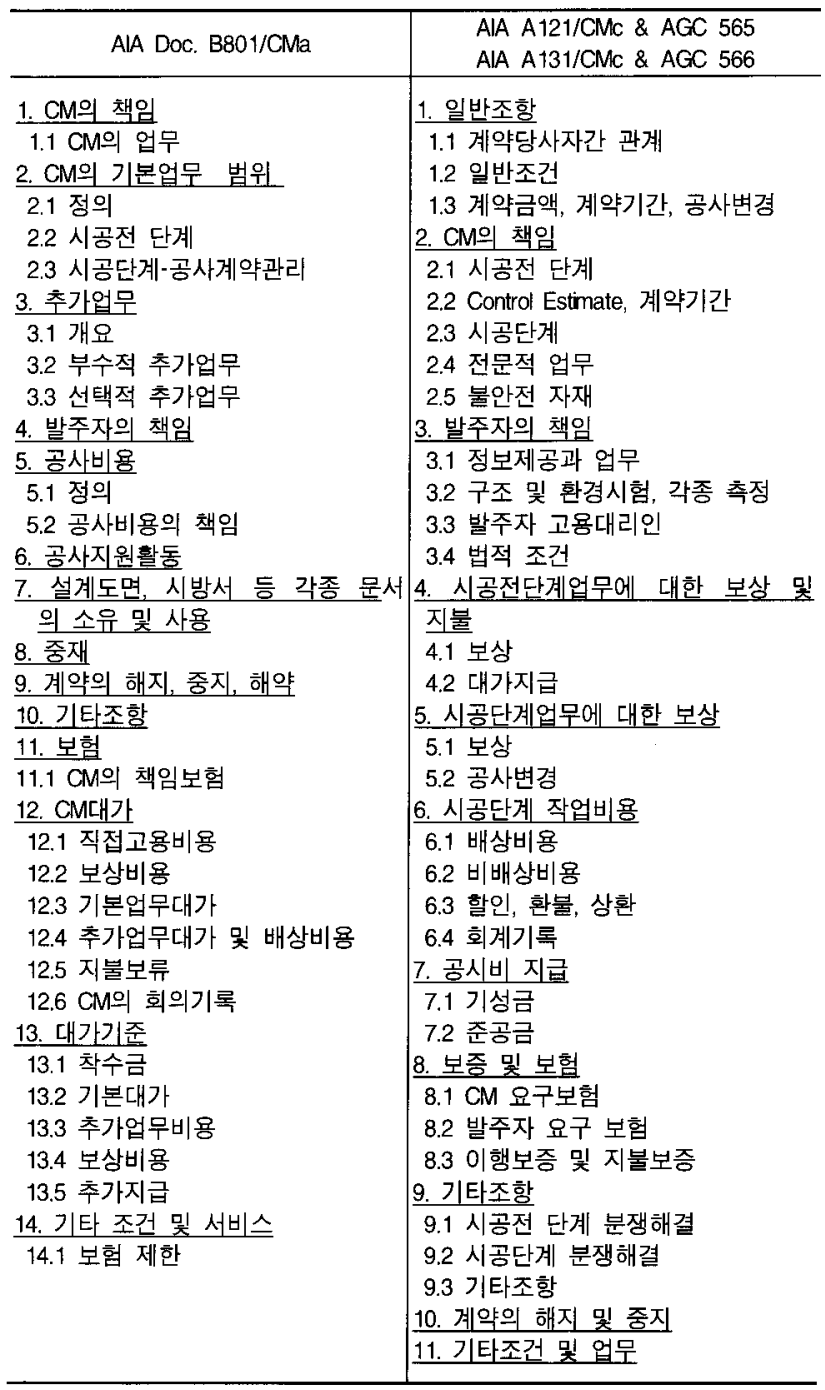


표 4. CMAA 표준계약서의 구성

\begin{tabular}{|c|c|}
\hline CMAA Doc. No. A-1 & CMAA Doc. No. GMP-1 \\
\hline 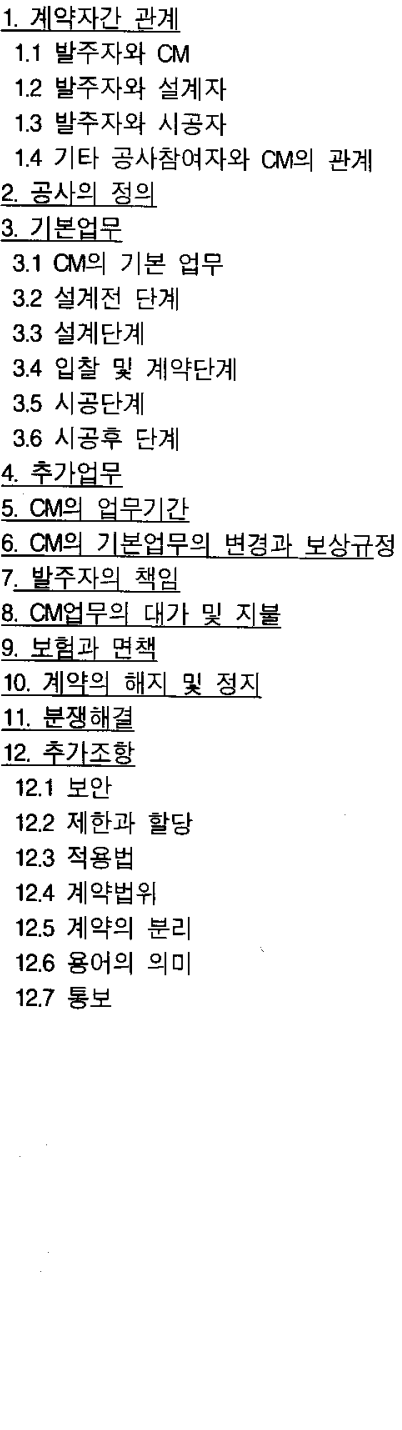 & 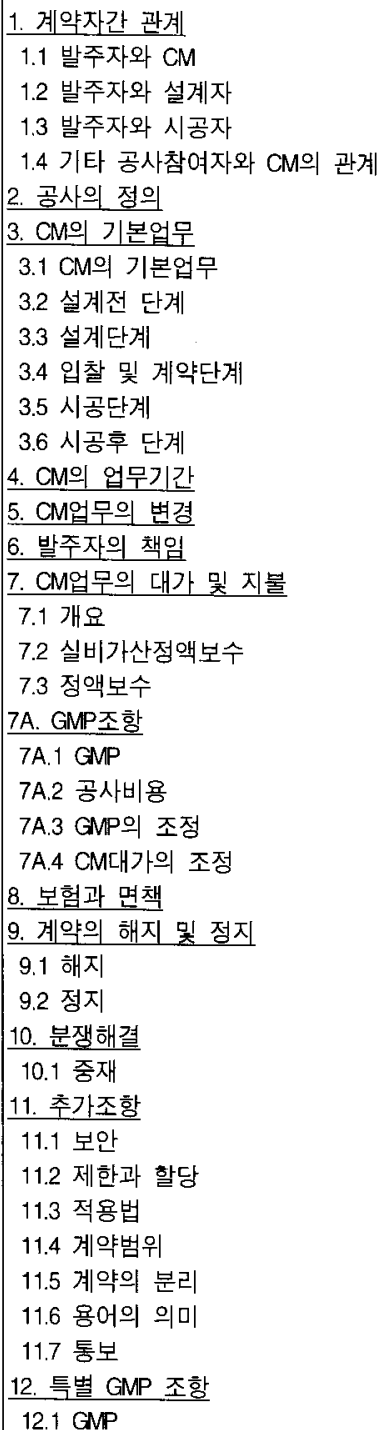 \\
\hline
\end{tabular}

\subsection{CM 표준계약서의 역할}

두 기관에서 제시하는 표준계약서는 $\mathrm{CM}$ 의 역할을 공사단계 별로 나타내고 있다. $\mathrm{CM}$ 의 업무는 크게 기획단계, 설계단계, 시공단계로 나누어 규정하고 있으나 기관에 따라 활동, 책임, 역할의 범위가 다소 상이하다. 본 연구에서는 두 기관의 발주 자-CM간 표준계약서를 바탕으로 $\mathrm{CM}$ 의 역할을 $\mathrm{CM}$ for Fee방 식을 대상으로 단계별로 비교하였고, 그 내용은 다음과 같다.

\subsection{1 기획단계}

발주자가 공사초기단계인 기획단계에서 $\mathrm{CM}$ 을 고용하는 주 된 목적은 사업기흭, 사업조건 및 시공성 검토 등에 대하여 $\mathrm{CM}$ 의 전문가적 의견을 공사계획에 반영할 수 있다는뎨 있다. 즉, $\mathrm{CM}$ 의 효과적 관리업무를 통해 전체공사에 가장 큰 영향을 미치는 기획단계에서 공사의 질을 극대화시키는뎨 그 목적이 있다.

$\mathrm{AIA}$ 는 건축사협회인 만큼 $\mathrm{CM}$ 이 설계자에게 검토나 승인을 거치는 다소 종속적인 역할로 나타내고 있다. $\mathrm{CM}$ for Fee방식
인 $\mathrm{AIA} \mathrm{B} 801 / \mathrm{CMa}$ 계약서상 $\mathrm{CM}$ 의 역할은 표 5 와 같다.

$\mathrm{CMAA}$ 는 $\mathrm{CM}$ 의 역할조항을 타기관보다 비교적 상세하게 나 타내고 있다. $\mathrm{CMAA}$ 는 기획단계인 설계전 단계동안 $\mathrm{CM}$ 의 역 할을 공사, 일정, 원가, 정보관리로 나누어 제시하고 있으며, $\mathrm{CM}$ for Fee방식인 CMAA Doc. No. A-1 계약서상 CM의 역할 은 표 6 과 같다.

표 5. 기획단계의 $\mathrm{AlA} \mathrm{B801/CMa} \mathrm{CM}$ 의 역할

\begin{tabular}{|c|c|}
\hline 기획단계 활동 & 상세활동사항 \\
\hline Project Program Review & $\begin{array}{l}\text { - 발추자의 공사계획검토 } \\
\text { - 발주자와 상호 이해 도달 }\end{array}$ \\
\hline Preminary Evaluation & $\begin{array}{l}\text { - 받주자의 공사조건, 일정 } \\
\text { - 예산조건의 예비평가수행 }\end{array}$ \\
\hline Preminary Estimate & - 설계자의 개념설계 및 설계기준에 군거한 개산견적수행 \\
\hline Project Schedule & $\begin{array}{l}\text { - 공사의 일정수립으로 설계자의 검토 후, 발주자의 승인 } \\
\text { - 발주자, } \mathrm{CM} \text {, 설계자의 업무의 조점 }\end{array}$ \\
\hline Professional Labor & $\begin{array}{l}\text { - 전문용역의 고용업무지원 } \\
\text { - 투입노무형태 및 규모의 검토 }\end{array}$ \\
\hline
\end{tabular}

표 6. 기획단계의 CMAA Doc. No. A-1 CM의 역할

\begin{tabular}{|c|c|}
\hline 기획단계 팔동 & 상세활동사항 \\
\hline Project Management & $\begin{array}{l}\text { - 일정, 비용, 설계조건을 고려한 시공관리체계의 수립 } \\
\text { - 설계자 선정 및 교육업무의 지원 }\end{array}$ \\
\hline Time Management & $\begin{array}{l}\text { - 공사일정이 지정된 기본일정 수립 } \\
\text { - 설계단계 이정표일정 수립 } \\
\end{array}$ \\
\hline Cost Management & $\begin{array}{l}\text { - 시공요소에 대한 시장조사실시 } \\
\text { - 시공관리계획과 시장조사를 바탕으로 공사시공예산 } \\
\text { 수립 } \\
\text { - 설계 및 시공 대안의 비교분석 }\end{array}$ \\
\hline MS & $\begin{array}{l}\text { - 계약자간 정보교환의 절차 수립 } \\
\text { - 설계단계동안 정보보고체계 확립 }\end{array}$ \\
\hline
\end{tabular}

\subsection{2 설계단계}

설계단계동안 $\mathrm{CM}$ 의 활동은 두 기관에 따라 다소 차이가 있 지만, 일정 및 예산의 수립, 설계업무의 지원, 설계도서의 검토 등 효율적인 시공을 위한 지원업무를 수행하게 된다.

AIA Doc. B801/CMa에 나타난 설계단계의 CM 역할은 세부 적이긴 하지만 업무수행에 있어 다소 설계자에게 종속적인 면 을 보여주고 있으며, CMAA Doc. No. A-1는 설계단계의 CM업 무를 설계지원 및 조정업무를 수행하는 설계자와 시공자 등의 계야자 선정업무를 지원하는 입찰 및 계얃단계로 나누어 제시 하고 있다.

표 7. 설계단계의 $\mathrm{AlA} \mathrm{B801/CMa} \mathrm{CM}$ 의 역할

\begin{tabular}{|c|c|}
\hline 설계단계 활동 & 상세활동사항 \\
\hline Design Doament Review & $\begin{array}{l}\text { - 설계도서검토로 공사수행체계에 대한 조언 } \\
\text { - 시공기법, 공사비용에 관한 조언 }\end{array}$ \\
\hline Project Schedie & $\begin{array}{l}\text { - 발주자, 설계자, CM의 업무 조점 및 통합 } \\
\text { - 이를 통한 공사일정 수립 }\end{array}$ \\
\hline Updating Estimate & $\begin{array}{l}\text { - 설계진행에 따른 견적비용 갬신 } \\
\text { - 공사예산 초과할 때, 발주자와 설계자에게 조언 }\end{array}$ \\
\hline Document Review & $\begin{array}{l}\text { - 시공성, 공사비용, 일정에 대하여 시공도서 검토 } \\
\text { - 시공요소 책임의 할담 및 계약도서 내의 포함여부 검토 }\end{array}$ \\
\hline Safety Program & - 안점관리 책임주체 설정 \\
\hline $\begin{array}{l}\text { Project Construction } \\
\text { Schedule }\end{array}$ & $\begin{array}{l}\text { - 시꽁단계, 작업일정, 조달일정 등이 포함된 공사일정 } \\
\text { 수립 }\end{array}$ \\
\hline Biddng / Award & $\begin{array}{l}\text { - 시공입찰자격의 목록 작성 } \\
\text { - 입찰문서 작성, 입찰평가 등의 입찰업무 수행 및 조언 } \\
\text { - 시공계약업무 지원 }\end{array}$ \\
\hline Permit \& License & - 발주자의 인허가 취독업무 지원 \\
\hline
\end{tabular}


표 8. 설계단계의 CMAA Doc. NNo. A-1 CM의 역할

\begin{tabular}{|c|c|}
\hline 기획단계 활동 & 상세활동사항 \\
\hline Project Management & $\begin{array}{l}\text { - 일정, 비용, 설계조건을 고려한 시공관리체계의 수립 } \\
\text { - 설계자 선점 및 표육업무의 지원 }\end{array}$ \\
\hline Tme Management & $\begin{array}{l}\text { - 공사일정이 지정된 기본일정 수립 } \\
\text { - 설계단계 이정표일정 수립 }\end{array}$ \\
\hline Cost Management & $\begin{array}{l}\text { - 시공요소에 대한 시장조사실시 } \\
\text { - 시공관리계확과 시장조사를 바탕으로 공사시공예산 } \\
\text { 수립 설계 및 시공 대안의 비교분석 }\end{array}$ \\
\hline MS & $\begin{array}{l}\text { - 계약자간 점보표환의 절차 수립 } \\
\text { - 설계단계동안 정보보고체계 확립 }\end{array}$ \\
\hline 설계단계 활동 & 상세활동사항 \\
\hline Project Management & $\begin{array}{l}\text { - 시공관리계획의 수정업무 지원 } \\
\text { - 공사회의 개최 } \\
\text { - 계약자간 정보흐름체계의 조정 } \\
\text { - 설계도서 검토 } \\
\text { - 규제기관의 인허가 취득업무 } \\
\text { - 추가계약조건의 작성 }\end{array}$ \\
\hline Tme Management & $\begin{array}{l}\text { - 기본일정수정업무 지원 } \\
\text { - 설계단계 이정표 일정의 감독 } \\
\text { - 입찰전 시공일점 수립 }\end{array}$ \\
\hline Cost Management & $\begin{array}{l}\text { - 작성된 설계도서를 토대로 시공비용 척산 } \\
\text { - 원가통제업무 수행 } \\
\text { - 설계변경에 따른 예산변경업무 지원 } \\
\text { - 기치분석 실시 }\end{array}$ \\
\hline MS & $\begin{array}{l}\text { - 설계단계 보고서의 작성 및 배포(일정 보고서, } \\
\text { 공사비용보고서, 현금흐름보고서, 설계변겸 보고서) }\end{array}$ \\
\hline 입찰/계약단계활동 & 상세활동사항 \\
\hline Project Management & $\begin{array}{l}\text { - 입찰참가자 목록 작성 및 샤전심사업무 지원 } \\
\text { - 입찰동지 및 입찰공고 업무 지원 } \\
\text { - 입찰서류의 교류 } \\
\text { - 입찰설명회개최 } \\
\text { : 입찰개시 업무 지원 } \\
\text { : 시공계약 업무 지원 } \\
\text { - 계약통지서 및 착공통지서 발급 }\end{array}$ \\
\hline Tme Management & - 기본일정 수정 제안 \\
\hline Cost Management & $\begin{array}{l}\text { - 입찰추가사항의 적산 } \\
\text { - 입찰가 분석 }\end{array}$ \\
\hline MS & $\begin{array}{l}\text { - 입찰 및 계약단계 보고서 작성 배포(일정 보고서, } \\
\text { 공사비용보고서, 현금흐름보고서) }\end{array}$ \\
\hline
\end{tabular}

\subsection{3 시공단계}

시공단계에서는 시공전 단계에 비하여 발주자에게 대리인 역할하게 된다. $\mathrm{CM}$ for $\mathrm{Fee}$ 방식에서는 $\mathrm{CM}$ 이 시공에 대한 직 접적인 책임이 거의 없이 대리인역할만을 수행하게 된다.

AIA Doc. B801/CMa에 나타난 가장 큰 특징은 $\mathrm{CM}$ 의 업무 가 설계자에게 검토를 거쳐야 하거나 공동으로 수행토록 하는 등 설계자에게 다소 수동적인 업무형태를 보이고 있다.

CMAA Doc. No. A-1에 나타난 표준계약서에서의 CM은 공 사의 전단계에 걸쳐 주도적으로 수행하고, 특히 시공단계동안 설계자의 지원을 받으며, 공사관리업무를 수행토록 하고 있다. $\mathrm{AIA}$ 와 차이점은 업무활동을 시공단계와 시공 후 단계로 세분 화하여 제시하고 있다.
표 9. 시공단계의 AIA B801/CMa CM의 역할

\begin{tabular}{|c|c|}
\hline 시공단계 활동 & 상세활동사항 \\
\hline Construction Admistration & $\begin{array}{l}\text { - 설계자와 협력하여 공사관리업무 수행 } \\
\text { - 시공회의 개최 } \\
\text { - 공사시공일정의 갱신 } \\
\text { - 시공순서 등의 시공자 작업조정 } \\
\end{array}$ \\
\hline Cost Management & $\begin{array}{l}\text { - 시공예산의 감독 } \\
\text { - 현금흐름 및 예촉보고서 작성 } \\
\text { - 공사의 회계기록 유지 } \\
\text { - 기성금 검토 및 지급절차 확립 }\end{array}$ \\
\hline Safety Program & - 시공자 안전계획의 조정 및 검토 \\
\hline Qualty Control & $\begin{array}{l}\text { - 계약조건에 따라 시공작업 검토 } \\
\text { - 조건 불만족 부분 설계자와 헙의하여 공사거부 }\end{array}$ \\
\hline Document interpretation & $\begin{array}{l}\text { - 설계도서 및 시방서에 관한 질의사항 설계자에게 전달 } \\
\text { - 문제의 해결업무 지원 }\end{array}$ \\
\hline Change Order & $\begin{array}{l}\text { - 시공자 공사변경요청 검토, 제안서 작성 및 제출 } \\
\text { - 변경안의 승인에 따라 공사변겸 지시서 작성 }\end{array}$ \\
\hline Claims & - 클레임 검토, 평가 듬 처리업무 지원 \\
\hline Sutrmittak Process & $\begin{array}{l}\text { - 시공도면 등 각종 시공자 제출서류의 처리 및 승인 } \\
\text { 절차수립 }\end{array}$ \\
\hline Progress Recorder & $\begin{array}{l}\text { - 공사 기성율을 기록하여 발주자 및 설계자에게 서면 } \\
\text { 보고 } \\
\text { - 기상, 작업인원, 장비 등의 기록유지 }\end{array}$ \\
\hline Complete Review & $\begin{array}{l}\text { - 운영장비의 최종검사 및 시운전 관촉 } \\
\text { - 사전 준공 검토할 때, 설계자와 함께 중요목록 작성 } \\
\text { - 준공결정을 위한 검사업무 지원 } \\
\end{array}$ \\
\hline
\end{tabular}

표 10. 시공단계의 CMAA Doc. No. A-1 CM의 역할

\begin{tabular}{|c|c|}
\hline 기획단계 활동 & 상셰촬동사항 \\
\hline Project Management & $\begin{array}{l}\text { - 일정, 설계조건올 고려한 시곻관려체계의 수립 } \\
\text { - 섰계자 선정 및 교욕업무의 지원 }\end{array}$ \\
\hline Time Management & $\begin{array}{l}\text { - 공사열정이 지정된 기본옐정 수립 } \\
\text { - 설계단계 이정표일정 수립 }\end{array}$ \\
\hline Cost Management & $\begin{array}{l}\text { - 시공요소어 대한 시장조사실시 } \\
\text { - 시공관리계획과 시장조사률 바탕으로 공사시공예산 } \\
\text { 수립 } \\
\text { - 설계 및 시공 대얀의 비교분석 }\end{array}$ \\
\hline MIS & $\begin{array}{l}\text { - 계약자간 정보교 완의 절차 수림 } \\
\text { - 설계단계동안 정보보고체계 확립 }\end{array}$ \\
\hline 시공단계 활동 & 상세활동사항 \\
\hline Project Management & $\begin{array}{l}\text { - 시공전 회의 및 현장회의 개최 } \\
\text { - 인가, 보험, 보증의 획득여부 확인 } \\
\text { - 현장관리요원 구성 } \\
\text { - 발주자의 대리인으로서 계약자간 점보교환 절차확립 } \\
\text { - 계약범위 내 최소 장업 변겸권 소유 } \\
\text { - 공사변경 관리체계의 확립, 시행 } \\
\text { - 품질검사체계의 확립 및 시행 } \\
\text { - 품질검사률 통해 부실공사 거부 } \\
\text { - 사공자의 안전계획 검토 } \\
\text { - 발주자 시공자간 분쟁해결 지원 } \\
\text { - 준공업무의 지원 }\end{array}$ \\
\hline Tme Management & $\begin{array}{l}\text { - 기본 일정의 조정 및 갱신 } \\
\text { - 시공자의 시공일정 검토 } \\
\text { - 공사 기성율의 검토 후, 발주자에게 조언(계획 대비 } \\
\text { 실행기성) } \\
\text { - 공사변경에 따론 일정의 염향 검토 및 조언 }\end{array}$ \\
\hline Cost Management & $\begin{array}{l}\text { - 공사비 일정의 확립 } \\
\text { - 시공비용 할당의 검토 } \\
\text { - 공사변경에 따른 원가의 영향 검토 및 조언 } \\
\text { - 시공요소에 대한 대안분석 실시 } \\
\text { - 기성금 지급업무 지원 }\end{array}$ \\
\hline MS & $\begin{array}{l}\text { - 시공단계 보고서의 작성 및 배포(일정 보고서, 공시비용 } \\
\text { 보고서, 예산변경 제안서, 연금흐름 보고서, 기성금 } \\
\text { 보고서, 공사변경 보고서) }\end{array}$ \\
\hline 시공후 단계 활동 & 상세활동사항 \\
\hline Project Management & $\begin{array}{l}\text { - 각종 기록도서의 조정 } \\
\text { - 최종 준공전 유지 매뉴얼, 보증서 등을 종합하여 } \\
\text { 발주자에게 보고 } \\
\text { - 점유허가 춰득 업무지원 }\end{array}$ \\
\hline Tme Management & - 잠비와 발주자촉 직원의 배치 등에 관한 점유계획 수립 \\
\hline Cost Management & $\begin{array}{l}\text { - 일정기간동안 공사변경에 따른 원가의 영향검토 업무 } \\
\text { 수행 }\end{array}$ \\
\hline MS & $\begin{array}{l}\text { - 시공 후, 단계보고서의 작성 및 배포(최종 보고서, MS } \\
\text { 보고서) }\end{array}$ \\
\hline
\end{tabular}




\section{$3.3 \mathrm{CM}$ 표준계약서의 비교 분석}

지금까지 살펴본 기획단계, 설계단계, 시공단계의 $\mathrm{CM}$ for $\mathrm{Fee}$ 의 업무는 AIA 및 CMAA 모두 발주자의 대리인으로서 역 할을 수행하고 있으며, 각 단계별 $\mathrm{AIA}$ 및 $\mathrm{CMAA}$ 의 $\mathrm{CM}$ 표준 계약서를 비교분석 결과는 다음과 같다.

1) 기획단계의 업무는 발주자의 대리인으로 사업의 타당성 평가, 공사관리체계의 확립 등 설계착수 이전 각종 공사 체계의 확립에 있다. 그러나 두 기관이 이러한 공통적인 업무를 수행토록 규정하고 있는 반면 활동범위, 검토 및 승인 조항 등에는 기관별 차이를 살펴볼 수 있다.

2) 설계단계의 업무는 발주자의 대리인으로 보다 효과적인 시공수행을 위하여 설계검토, 공사일정 및 예상편성, 적절 한 시공자 선정을 위한 입찰업무지원 등으로 크나 나눌 수 있다. 이러한 업무는 두 기관의 표준계야서에 공통적 으로 제시하고는 있으나 설계자와의 관계에 대해서는 차 이를 나타내고 있다.

3) 시공단계의 $\mathrm{AIA}$ 계야서상의 $\mathrm{CM}$ 업무는 각종업무에 대하 여 설계자와 책임을 분담하는 특징을 살펴볼 수 있다. 또 한 $\mathrm{CMAA}$ 계약서상의 $\mathrm{CM}$ 업무는 $\mathrm{CM}$ 이 보다 능동적인 역할로 업무를 수행하도록 제시하고 있다. 이러한 기관별 $\mathrm{CM}$ 업무의 특징은 기관의 업역과 구성주체에 따라 차이가 있음을 알 수 있다.

표 11. $\mathrm{AlA}$ 의 $\mathrm{CM}$ 표준계약서의 분석

\begin{tabular}{|c|c|c|}
\hline 구분 & 구분 & AIA Doc. B801/CMa \\
\hline \multirow{3}{*}{ 기획단계 } & $\begin{array}{l}\text { 공사계획 및 } \\
\text { 일정 }\end{array}$ & $\begin{array}{l}\text { - 공사일정 수립하여 설계자 검토 후 발주차 승인 } \\
\text { - 설계자의 업무부분은 설계자의 승인 필요 }\end{array}$ \\
\hline & 공사예산 & - 공사예산 수립하여 설계자 검토 후 밭주자 승인 \\
\hline & 설계자 선정 & - \\
\hline \multirow{2}{*}{ 설계단계 } & \begin{tabular}{|l} 
설계도서, 계 \\
약도서 검토
\end{tabular} & - 설계도서 검토후 설계에계 조언 \\
\hline & 입찰업무 & $\begin{array}{l}\text { - 발주자의 입찰업무지원 } \\
\text { - 설계자의 입찰추가사항 발행업문 지원 }\end{array}$ \\
\hline \multirow{6}{*}{ 시공단계 } & 공사관리 & - 설계자와 협력하여 시공계약관리 \\
\hline & 품질검사 & - 설계자와 협의하여 부실공사 겨부 \\
\hline & $\begin{array}{l}\text { 각 종 서 류 의 } \\
\text { 검토 }\end{array}$ & $\begin{array}{l}\text { - 설계도서와 시방서의 해석에 관한 사함은 설계자에게 전달 } \\
\text { - 설계자와 협의하여 시공자의 각종 체출물 검토체계 확립 }\end{array}$ \\
\hline & 공사변경 & $\begin{array}{l}\text { - 곻사변경제안을 발주자와 설계자에게 제출 } \\
\text { - 설계자의 수정안 삽입하여 공사변겸 요청서 작성 }\end{array}$ \\
\hline & 클레임 업무 & - 설계자와 클례임 검토 및 평가업무 지원 \\
\hline & 준공결정 & - 최종준공 겁토시 설계자와 함께 중요목록 작성 \\
\hline
\end{tabular}

표 12. $\mathrm{CMAA}$ 의 $\mathrm{CM}$ 표준계약서의 분석

\begin{tabular}{|c|c|c|}
\hline 구분 & 구분 & CMAA Doc. No. A-1 \\
\hline \multirow{3}{*}{ 기획단계 } & $\begin{array}{l}\text { 공사계획 및 } \\
\text { 일정 }\end{array}$ & - 시공관리계획과 기본일정을 수립하여 발주자 승인 \\
\hline & 공사예산 & - 공사예산 수립후 발주자, 설계자 검토 \\
\hline & 설계자 선정 & - 설계자 선정 및 계약업무 지원 \\
\hline \multirow{2}{*}{ 설계단계 } & $\begin{array}{l}\text { 설계도서, 계 } \\
\text { 약도서 검토 }\end{array}$ & - 설계도서 검토하여 발주자와 설계자에게 조언 \\
\hline & 입찰업무 & $\begin{array}{l}\text { - 발주자의 입찰업무 지원 } \\
\text { - 설계자위 입찰 추가사항 검토 }\end{array}$ \\
\hline \multirow{6}{*}{ 시공단계 } & 공사관리 & - 발주자의 대리인으로 현장관리팀 구성 \\
\hline & 품질겁사 & - 시공품질의 감독 및 부실작업의 거부절차 확립 및 시햄 \\
\hline & $\begin{array}{l}\text { 각 종 서 류 의 } \\
\text { 겁토 }\end{array}$ & $\begin{array}{l}\text { - 계약도서의 해석, 시공도면 등의 검토체계 확립 } \\
\text { - 시공자의 각종 제출물은 검토 후, 설계자에게 전달 }\end{array}$ \\
\hline & 공사변경 & $\begin{array}{l}\text { - 공사변경 통제체계확립 } \\
\text { - 서공자의 변겸요청안 검토하여 발주자에게 조언 }\end{array}$ \\
\hline & 클레입 업무 & - 발주자-시공자간 분쟁해결 지원 \\
\hline & 준공결점 & - 설계자와 협의하여 중요목록 작성 후 최종준공일 결정 \\
\hline
\end{tabular}

이상과 같이, 앞 절에서 $\mathrm{AIA}$ 와 $\mathrm{CMAA}$ 의 $\mathrm{CM}$ 표준계약서의 구성과 역할을 비교 분석하였다. 이 두 기관은 $\mathrm{CM}$ 을 능동적으 로 운영할 수 있는 법적인 제도적 장치를 마련하여 체계적으로 운영하고 있음을 알 수 있다.

\section{4. 국내CM제도의 문제점 및 정착화 방안}

국내 $\mathrm{CM}$ 체계는 구미의 필요 발생적 형태와는 달리 제도적 틀에 맞추어 도입되었는데, 각종 법규나 제도적 장치가 마련되 어야 그에 따른 조속한 적용이 가능하며, $\mathrm{CM}$ 의 활용 중에 반 복적인 시행착오를 통해 국내 상황에 맞는 갱신도 가능하게 된 다. 그러나 정부는 $\mathrm{CM}$ 제도를 건설산업기본법에서 몇몇의 대규 모 공사에 단순형태로만 언급해 놓았을 뿐 $\mathrm{CM}$ 의 표준계약서, 표준지침서, 시행규칙 등의 제도적 장치가 마련되어 있지 않아 $\mathrm{CM}$ 개념의 도입에 큰 흔란을 빚고 있다. 따라서 이 절에서는 이러한 제도적 장치의 미비로 발생되는 문제점들을 개선하기 위하여 앞 절에서 언급한 $\mathrm{AIA}$ 및 $\mathrm{CMAA}$ 기관에서 제시한 $\mathrm{CM}$ 표준계약서를 근거로 $\mathrm{CM}$ 의 업무범위 및 기술능력기준 확립, $\mathrm{CM}$ 자격조건의 제정기준, $\mathrm{CM}$ 의 선정 절차 구축, $\mathrm{CM}$ 계야ㄱㅗㅗ 서의 제정을 시안으로 제안하였다.

\subsection{CM 단계별 업무 및 기술능력}

다음은 앞 절의 $\mathrm{AIA}$ 및 $\mathrm{CMAA}$ 기관의 $\mathrm{CM}$ for Fee방식의 표준계약서 AIA Doc. B801/CMa 및 CMAA Doc. No. A-1를 비교, 분석한 내용을 종합한 결과를 근거로 효율적인 $\mathrm{CM}$ 운영 을 위해 반드시 존재해야할 공사 단계별 $\mathrm{CM}$ 의 업무범위를 제 안하고자 한다.

\subsection{1 기획단계}

기획단계의 업무는 표 13 과 같이 기술업무뿐만 아니라 기획, 타당성검토, 관리계흭수립, 경제성 예측 등의 검토, 분석, 예측 의 업무가 필요하다. 따라서 기획단계의 소요기술능력은 현장 경험과 지식이 많은 특급기술자 이상의 기술능력과 검토, 분 석, 예측업무를 수행할 수 있는 경영, 경제, 회계 조직관리 둥 의 사업관리계통의 기술능력이 보유되어야 한다.

표 13. 기획단계의 업무 활동(안)

\begin{tabular}{|c|c|}
\hline 기획단계 업무활동 & Activities of Planning Phase \\
\hline - 계략견적수립 & Development of Prelminary Estimates \\
\hline - 개략일정수립 & Development of Pretrinary Schedules \\
\hline $\begin{array}{l}\text { - 리스크분석 정보 } \\
\text { 제공 }\end{array}$ & Provision of hout to Risk Analysis \\
\hline - 시공성 분석 & Constructabity Analysis \\
\hline - 시공상 문제점 확인 & Identification of Potential Major Construction Problem \\
\hline - 자원조건수립 & Development of Resource Requirements \\
\hline - 예산확보지원 & Assistance of Development of Capital Budgets \\
\hline - 현금 흐름 예측 & Development of Cash-Flow Projections \\
\hline - 계략일정갱신 & Update of Prelminary Scheddes \\
\hline $\begin{array}{l}\text { - 공사정보관리체계수 } \\
\text { 립 }\end{array}$ & Development of Project Management information System \\
\hline - 안전계획 수립 & Development of Safety Program \\
\hline $\begin{array}{l}\text { - 보증보험계획수립지 } \\
\text { 원 }\end{array}$ & Assistance of Development of Bond and hsurance Program \\
\hline
\end{tabular}




\subsection{2 설계단계}

설계단계의 업무는 표 14 와 같이 설계검토, 시공성검토, $\mathrm{VE}$ 적용 등의 직접적인 설계관련 업무 외에 업무조정, 일정수립, 조달, 공사비 적산, 입찰 등 조정, 관리, 회계업무를 수행하게 되므로 엔지니어링, 설계감리 분야와 설계에 시공성을 반영할 수 있는 현장경험, 기술능력 등이 요구된다. 따라서 기존의 설 계감리업무와 설계용역업의 기준을 상희하는 다수의 기술능력 이 보유되어야 한다.

표 14. 설계단계의 업무 활동

\begin{tabular}{|c|c|}
\hline 설계단계 업무활동 & Activities of Design Phase \\
\hline - 공사계획수립 & Development of Project Planring \\
\hline $\begin{array}{l}\text { - 생애주기비용의 } \\
\text { 수립 } \\
\end{array}$ & Development of Project Lile-Cyde-Costs \\
\hline $\begin{array}{l}\text { - 비용대안분석의 } \\
\text { 평가 }\end{array}$ & Evaluations of Cost Trade-offs \\
\hline - VE기능의 제공 & Provision of Value Engineering \\
\hline $\begin{array}{l}\text { - Long-Lesd-Tme품목 } \\
\text { 의 조달 }\end{array}$ & Procurement of Long-Lesd-Tme Hems \\
\hline - 공사일정 수립 & Development of Project Schedules \\
\hline - 인허가의 취특 지원 & Assistance of Permits and Licenses \\
\hline $\begin{array}{l}\text { - 계약서류에 관한 } \\
\text { 정보제공 및 검토 }\end{array}$ & Provision of nout and Review of Contract Documents \\
\hline $\begin{array}{l}\text { - } \mathrm{PQ} \text { 입찰자 리스트 } \\
\text { 작성 }\end{array}$ & Development of Pre-qualfication Bidders Lists \\
\hline - 입찰자 자격 평가 & Qualification of Potential Bidders \\
\hline $\begin{array}{l}\text { - 입찰서의 접수 및 } \\
\text { 평가 }\end{array}$ & Receipt and Evaluation of Bids \\
\hline - 계약체결 업무지원 & Assistance of Contract Award \\
\hline
\end{tabular}

\subsection{3 시공단계}

시공단계의 업무는 건설공사의 단계별 계 약기간중 수행기간 이 가장 길며, 투입인원 및 처리업무가 방대하기 때문에 $\mathrm{CM}$ 은 기획, 설계단계보다 범위가 넓은 엄무영역을 담당하게 된다. 따라서 표 15 와 같이 기존의 공사수행주체 중에 시공감리의 주 업무인 시공활동의 감독, 통제업무뿐만 아니라 일정, 작업조정, 구매업무, 각종 관리업무 등 시공 활동상의 제반 업무를 수행 하게 될 종합감리전문회사 면허기준 이상의 기술능력이 보유 되어야 한다.

표 15. 시공단계의 업무 활동

\begin{tabular}{|c|c|}
\hline 시공단계활동 & Activities of Constructionu Phase \\
\hline - 노무관계의 조정 & Coorcination of Labor Relations \\
\hline - 현장작업의 관리 & Management of Site Work \\
\hline $\begin{array}{l}\text { 일정 및 } \\
\text { 원가관리체계의 } \\
\text { 시행 } \\
\end{array}$ & Implementation of Tme and Cost Management System \\
\hline - 계약관리 & Adrinistration of Contacts \\
\hline $\begin{array}{l}\text { - 기성금지급 업무 } \\
\text { 지원 }\end{array}$ & Assistance of Progress Payment \\
\hline $\begin{array}{l}\text { - 계약변겸 및 콜레임 } \\
\text { 관리 }\end{array}$ & Management of Contract Changes and Claims \\
\hline $\begin{array}{l}\text { - 품질보증 및 } \\
\text { 검사체계 확립 }\end{array}$ & Development of Quarity Assurance and Inspection System \\
\hline $\begin{array}{l}\text { - 계약도서의 } \\
\text { 해석업무지원 }\end{array}$ & Assistance of Contract Documents interpretation \\
\hline - 꽁사종료업무지원 & Assistant of Project Closeout \\
\hline $\begin{array}{l}\text { - 공사물의 시험, } \\
\text { 시운전의 준비 }\end{array}$ & Preparation of Testing and Start-Up \\
\hline
\end{tabular}

지금까지 $\mathrm{AIA}$ 및 $\mathrm{CMAA}$ 기관의 공사단계별 $\mathrm{CM}$ 표준계약 서의 업무 내용을 분석 종합한 내용을 토대로 효율적인 $\mathrm{CM}$ 운 영을 위하여 반드시 존재되어야 할 업무범위와 공사단계별 업 무에 따른 $\mathrm{CM}$ 의 면허설정 기준을 간략히 제시하였다. 건설공 사에 투입될 $\mathrm{CM}$ 조직을 해당공사의 성격이나 특징을 파악하여 각 공사단계별 업무에 필요한 해당 기술인력을 적절히 제공하 여야 하며, 각 단계별 수행주체, 즉 설계자, 시공자, 감리자가 소유한 능력이나 경험 이상의 기술능력을 갖추어야 적절한 조 정, 통제, 관리업무를 수행할 수 있을 것이다.

\section{$4.2 \mathrm{CM}$ 자격조건의 제정기준}

건설산업 관련분야의 기술능력에 대한 면허기준 중 가장 높 은 기술능력을 요하는 업종은 설계 및 시공감리업이다. 이는 설계 및 시공 수행주체의 경험, 기술능력보다 한층 숙련된 먼 허기준의 적용을 통하여 설계 및 시공의 각 단계별 수행업무를 원활하게 감독, 통제하기 위한 기준으로 사료된다. 따라서 기 존의 책임감리업무보다 폭넓은 업무를 수행하며 건설공사의 기획, 설계, 조달, 시공 등의 업무영역을 관리, 감독, 조정, 통제 하는 $\mathrm{CM}$ 의 자격조건은 건설산업기본법에서 나타낸 바와 같이 건설사업관리에 관한 전문지식과 기술능력을 갖춘 보다 강화 된 면허기준이 설정되어야 한다. 다음 표 16은 본 연구에서 제 안하는 단계별 $\mathrm{CM}$ 기술능력의 소요기준을 제안한 것으로서 기 존의 건설관련 업종의 면허기준을 상회하는 $\mathrm{CM}$ 전문업체 등 록규정의 제정을 통한 건설사업의 효과적 조정, 관리, 통제를 수행할 수 있어야 할 것으로 판단된다.

표 16. 단계별 $\mathrm{CM}$ 기술능력의 소요기준(안)

\begin{tabular}{|c|c|c|}
\hline 기획단계 & 설계단계 & 시공단계 \\
\hline $\begin{array}{l}\text { - 기술관련 특급기술자 } \\
\text { 공사기횐, 관리계획 } \\
\text { - 기회, 분석, 관리부분 } \\
\text { 고급기술자 } \\
\text { 사업의 겁토, 분석, } \\
\text { 예측업무 }\end{array}$ & $\begin{array}{l}\text { - 설계관련 고급기술자 } \\
\text { 설계시공성 겁토, } \mathrm{VE} \text { 등의 } \\
\text { 설계조정업무 } \\
\text { - 관리, 회계관련 고급기술자 } \\
\text { 예산수립, 업무조정 등의 } \\
\text { 관리, 조정 업무 }\end{array}$ & $\begin{array}{l}\text { 사업관리관련 고급기술자 } \\
\text { 전반적인 사업조정 및 } \\
\text { 관리업무 } \\
\text { - 현장작업관리관련 } \\
\text { 중급기술자 } \\
\text { 공사관리, 공사품질 등 } \\
\text { 현장관리업무 }\end{array}$ \\
\hline
\end{tabular}

\section{3 $\mathrm{CM}$ 의 선정 절차 확립}

국내 $\mathrm{CM}$ 의 시행초기 개념과 정의의 미비에 따른 명확한 $\mathrm{CM}$ 선정기준 및 절차의 부재로. 적절한 $\mathrm{CM}$ 조직의 선정에 난항 을 격고 있다. 따라서 국내여건에 맞는 $\mathrm{CM}$ 선정절차 및 그에 따른 기준의 설정이 선행되어야 한다. 사업에 가장 적절한 $\mathrm{CM}$ 조직을 선정하는 절차기준은 가격위주의 선정이 아닌 능력위 주의 선정이 되어야 한다. 그러므로 $\mathrm{CM}$ 용역입찰은 $\mathrm{CM}$ 조직의 능력과 경혐, 현장지식, 재무상태 등 각종 업무능력에 따라 순 위가 매겨지는 적격업체를 우선 선정하고, 이 중에서 상위업체 와 비용에 관한 협상을 통하여 계약을 체결하는 선정절차를 채 용해야 한다. 이러한 기준에 근거하여 본 연구에서 그림 2 와 같이 $\mathrm{CM}$ 업체의 선정절차를 제안하였으며, 그 내용을 설명하면 다음과 같다.

\subsection{1 제1단계 : $\mathrm{CM}$ 참가 및 업무범위 설정}

일반적으로 $\mathrm{CM}$ 은 소규모 공사 등에는 적절치 못한 수행방 식이므로 발주자는 사업목적에 따라 $\mathrm{CM}$ 적용의 효과와 투입비 
용분석을 실시하여 $\mathrm{CM}$ 채용여부를 결정해야 한다. $\mathrm{CM}$ 용역의 채용이 결정되면 발주자는 $\mathrm{CM}$ 업무범위를 설정하고 정량화하 여 적절한 $\mathrm{CM}$ 선정기준을 제정한다.

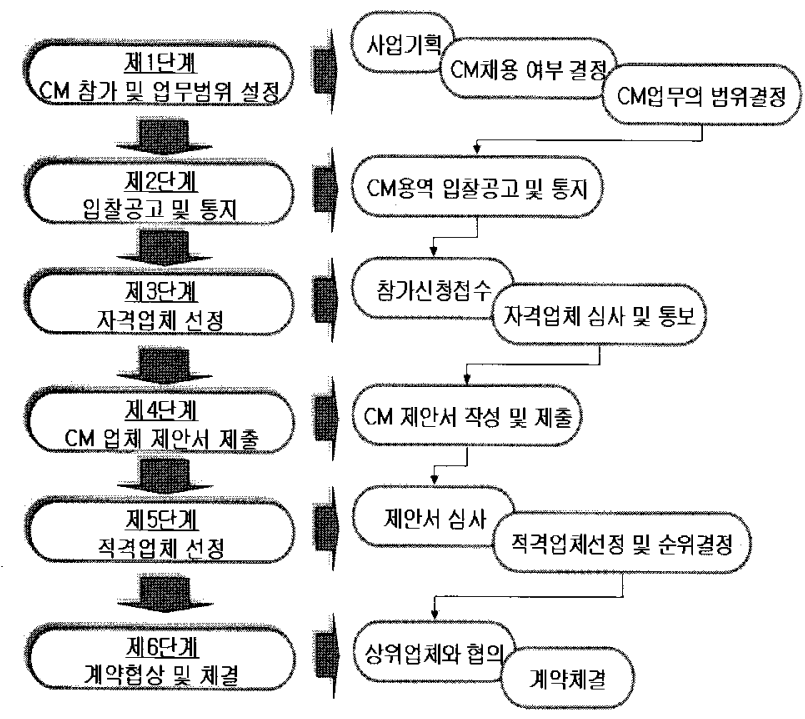

그림 2. $\mathrm{CM}$ 선정절차(안)

\subsection{2 제 2 단계 : 입찰공고 및 통지}

$\mathrm{CM}$ 채용이 결정되면 각종 일간지 둥에 공사개요, 참가자격, 선정방법 등의 제반사항을 공고하여야 한다. 또는 일반공사의 제한입찰에 준하는 경우 적절한 $\mathrm{CM}$ 업체를 선정하여 통지서를 발송한다.

\subsection{3 제3단계 : 자격업체 선정}

발주자 조직은 $\mathrm{CM}$ 업체의 입찰참가 신청서를 바탕으로 제 안서를 제출 대상업체를 선정하는 자격심사를 실시한다. 일반 적인 자격업체 선정기준은 당해사업과 유사한 사업의 참여경 험, 사업의 수행능력 보유여부, 자체보유 조직의 확보 및 능력, 수행업무의 범위, 재무능력 및 재무적 안정성이다.

\subsection{4 제4단계 : $\mathrm{CM}$ 업체의 제안서 제출}

발주자는 자격업체로 선정된 $\mathrm{CM}$ 업체에게 제안서를 제출하 도록 요청해야 하며, 이에 따라 $\mathrm{CM}$ 업체는 수행용역, 관리계획 등을 기술한 제안서를 작성, 제출하야 한다. $\mathrm{CM}$ 의 작업수행능 력은 효과적인 제안서 작성능력에 따라 좌우된다. $\mathrm{CM}$ 업체의 제안서 작성목표는 최소 공기와 예산내에서 소요 품질을 제공 할 수 있는 능력을 발주자에게 확신시키고자 하는 것이므로 간 결하고 이해하기 쉽도록 작성해야 한다.

\subsection{5 제 5 단계 : 적격업체의 선정}

발주자는 $\mathrm{CM}$ 업체가 제출한 제안서를 바탕으로 분야별 평 가기준에 각 항목을 적용하여 순위가 매겨지는 적격업체를 선 정하여야 한다. 적격업체의 순위는 이후 계약협상의 대상이 되 므로 객관적으로 설정된 평가기준에 따라 공정한 심사를 거쳐 야 한다.

적격업체 선정단계에서는 다음 표 17과 같은 선정기준이 포 함되어야 한다.
표 17. 적격업체 선정기준 포함 사항 (안)

\begin{tabular}{l}
\hline 해당사업의 이해정도 \\
- 제안된 관리계획의 적절성 \\
- 유사공사 사업수행실적 \\
\hline - 해당긍사에 맞는 조직의 보유여부 \\
\hline - 재점능력의 실용도 \\
\hline 현재 수햄공사의 중첩도 \\
\hline 현장주변지역의 지식 \\
\hline 연구 및 기술개발 실적 \\
\hline
\end{tabular}

\subsection{6 제6단계 : 계약 및 헙상 체결}

발주자는 기 선정된 적격업체중 가장 상위의 $\mathrm{CM}$ 업체와 보 수 등의 계약조건에 관하여 협상을 실시하여야 한다. CM용역 에 소비된 비용은 효과적인 관리 및 조정활동에 따라 복구되므 로 $\mathrm{CM}$ 의 보수는 사업단계에 수행될 업무에 따라 결정되어야 하며, 단순히 공사비의 비율에 따라 결정되어서는 안 된다. 만 일 최상위 업체와의 협상이 결렬된 경우 다음 순위의 업체와 협상을 재개할 수 있다.

\section{$4.4 \mathrm{CM}$ 계약도서의 제정}

\subsection{1 $\mathrm{CM}$ 표준계약서}

$\mathrm{CM}$ 계약뿐만 아니라 모든 건설사업 수행방식의 계약체결을 위해서는 표준계야서, 공사계약일반조건 등의 문서체계가 우선 되어야 한다. 특히, 국내에서 도입초기인 $\mathrm{CM}$ 수행방식은 체계 적인 문서정립이 선행되어야 신속한 정착을 이룰 수 있을 것이 다. 이러한 표준계약서는 공공발주기관인 행정기관뿐만 아니라 관련협회나 학회에서 각 공사참여자의 의견을 수렴, 조율하여 역할, 업무범위, 책임과 공사의 범위, 대가규정 등을 $\mathrm{CM}$ 계약의 형식에 따라 제정하여야 한다. 이렇게 다양하게 작성된 계약서 는 해당공사의 특성과 계약방식에 맞추어 선정, 사용될 수 있 으며, 또한 다수의 계약서를 취합, 보완, 조정하여 공사에 맞는 계약서를 제정함으로써 유연성 있는 계약체결이 가능하게 된 다. 발주자-CM간의 표준계약서를 제정할 때, 작성주체는 표 18 의 사항을 유의하여야 한다.

표 18. 발주자-CM간의 표준계약서 제정시 유의사항

\begin{tabular}{|c|c|}
\hline 항 목 & 유의샤항내용 \\
\hline $\begin{array}{l}\text { 발주자와 } \mathrm{CM} \text { 간 법적합의 기준 } \\
\text { 의 명확화 }\end{array}$ & $\begin{array}{l}\text { - 발주자와 CM간의 수행업무의 뚜렷한 설정 } \\
\text { - } \mathrm{CM} \text { 업무 규정시 기본업무와 추가업무 구분의 명확화 } \\
\text { - } \mathrm{CM} \text { 대가기준, 지급시기, 지급방법의 명확한 제시 }\end{array}$ \\
\hline $\begin{array}{l}\mathrm{CM} \text { 계약형태에 따른 별도 계약 } \\
\text { 서 제정 }\end{array}$ & $\begin{array}{l}\text { - 계양방식에 다를 } \mathrm{CM} \text { 업무범위의 규점 } \\
\text { - 계갹형태에 다론 대가기준의 설정 } \\
\text { - 계약형태에 따른 사업단계벌 CM의 역할과 업무의 설점 }\end{array}$ \\
\hline $\begin{array}{l}\text { 계약수행에 따른 분쟁 발생요 } \\
\text { 인 최소화 }\end{array}$ & $\begin{array}{l}\text { - } \mathrm{CM} \text {, 설계자, 시공자 등 공사참여자간의 관계설정의 명 } \\
\text { 화화 } \\
\text { - 계약 및 공사변경 처리절차의 명확화 } \\
\text { - 관련 및 연계 문서의 제시 }\end{array}$ \\
\hline 분쟁발생시의 해결방법 제시 & $\begin{array}{l}\text { - CM업무영역 명확화 } \\
\text { - 상호간 책임소재의 기준설점 } \\
\text { - 분쟁발생에 따른 조정, 중재 절차의 명확화 }\end{array}$ \\
\hline $\begin{array}{l}\text { 장기간 계약시 종료일까지의 } \\
\text { 각종 변동요소 고려 }\end{array}$ & - 공가변동에 따른 변동요소 고려 \\
\hline
\end{tabular}

그리고 표준계약서에 따른 공사계약일반조건 또한 기존의 단편적 일반조건뿐만 아니라 $\mathrm{CM}$ 계약의 각종 유형에 맞는 공 사계약일반조건, 즉 $\mathrm{CM}$ for Fee방식과 $\mathrm{CM}$ at Risk방식에 따른 각각의 공사계약일반조건의 제정이 필요하지만, 본 연구에서는 
$\mathrm{CM}$ for Fee계약방식을 기준으로 표준계약서 제정(안)을 제시 하였다.

표 19. 발주자-CM간 표준계약서 제정(안)

\begin{tabular}{|c|c|}
\hline 조 항 & 포 함 내 용 \\
\hline $\begin{array}{l}\text { 제1조 정의 } \\
\text { (Definition) }\end{array}$ & $\begin{array}{l}\text { - 곻사 및 계약의 정의와 범위 } \\
\text { - 용어의 정의 }\end{array}$ \\
\hline $\begin{array}{l}\text { 제2조 계약자 관계 } \\
\text { (Relationship) } \\
2.1 \text { 발주자-CM } \\
2.2 \mathrm{CM} \text {-설계자 } \\
2.3 \mathrm{CM} \text {-시공자 } \\
\end{array}$ & - 공사참여자간 관계의 정의 및 상호 정보교환체계 설정 \\
\hline $\begin{array}{l}\text { 제3조 } \mathrm{CM} \text { 의 기본업무 } \\
\text { (CM's Basic Service and } \\
\text { Responsibility) } \\
3.1 \text { 기획단계 } \\
3.2 \text { 설계단계 } \\
3.3 \text { 입찰단계 } \\
3.4 \text { 시공단계 } \\
\end{array}$ & $\begin{array}{l}\text { - 각 단계별 } \mathrm{CM} \text { 의 역할과 책임의 정의 } \\
\text { (공사관리, 일정관리, 원가관리) }\end{array}$ \\
\hline $\begin{array}{l}\text { 제 } 4 \text { 조 } \mathrm{CM} \text { 의 추가업무 } \\
\text { (CM's Additional Services) }\end{array}$ & $\begin{array}{l}\text { - 발주자의 요구에 따른 기본업무의 전문적 추가용역의 } \\
\text { 설정 }\end{array}$ \\
\hline $\begin{array}{l}\text { 제5조 발주자의 책임 } \\
\text { (Owner's Responsibilies) } \\
5.1 \text { 기획단계 } \\
5.2 \text { 설계단계 } \\
5.3 \text { 입찰단계 } \\
5.4 \text { 시공단계 }\end{array}$ & $\begin{array}{l}\text { - 각 단계별 발주자의 체계적인 업무 및 책임사항의 정 } \\
\text { 의 }\end{array}$ \\
\hline $\begin{array}{l}\text { 제6조 } \mathrm{CM} \text { 업무대가 } \\
\text { (Payment for CM Service) }\end{array}$ & $\begin{array}{l}\text { - CM대가기준, 지급시기, 방법 } \\
\text { - 기본업무 비용 } \\
\text { - 추가업무 비용 }\end{array}$ \\
\hline $\begin{array}{l}\text { 제 } 7 \text { 조 } \mathrm{CM} \text { 업무 몇 대가 변경 } \\
\text { (Change of } \mathrm{CM} \text { Services and } \\
\text { Payment) }\end{array}$ & $\begin{array}{l}\text { - 기본업무변겸 규정 } \\
\text { - 그에 따른 대가와 방식의 기준 결정 }\end{array}$ \\
\hline $\begin{array}{l}\text { 제8조 보험 및 보증 } \\
\text { (Insurance and Bonds) }\end{array}$ & $\begin{array}{l}\text { - 발주자와 } \mathrm{CM} \text { 의 취득 보험 및 보증의 규정 } \\
\text { - 보험 및 보증의 운영기준 설정 }\end{array}$ \\
\hline $\begin{array}{l}\text { 제9조 공사변경 } \\
\text { (Changes) }\end{array}$ & $\begin{array}{l}\text { - 공사변경에 따른 } \mathrm{CM} \text { 행동절차 규정 } \\
\text { - } \mathrm{CM} \text { 과 발주자의 업무체계 설정 }\end{array}$ \\
\hline $\begin{array}{l}\text { 제 } 10 \text { 조 분쟁해결 } \\
\text { (Dispute Resolution) }\end{array}$ & $\begin{array}{l}\text { - 발주자에 대한 } \mathrm{CM} \text { 의 분쟁해결 업무기준 설정 } \\
\text { - 발주자-CM간 분쟁, 클레임조정, 중재 등 해결절차규정 }\end{array}$ \\
\hline $\begin{array}{l}\text { 제11조 계약의 해지 및 정지 } \\
\text { (Termination and Suspens- } \\
\text { ion) }\end{array}$ & $\begin{array}{l}\text { - 발주자나 CM에 의한 계약의 해지 및 정지사유, 문서 } \\
\text { 절차규정 } \\
\text { - 해지나 정지에 따른 대가, 비용처리절차 }\end{array}$ \\
\hline $\begin{array}{l}\text { 제 } 12 \text { 조 기타조항 } \\
\text { (Other Provisions) }\end{array}$ & $\begin{array}{l}\text { - 발주자와 } \mathrm{CM} \text { 간 합의에 따른 추가적, 부수적 조항 삽 } \\
\text { 입 } \\
\text { - 연계문서의 제시 }\end{array}$ \\
\hline
\end{tabular}

\subsubsection{CM 표준업무지침서}

$\mathrm{CM}$ 업무를 수행하는 관련 업체뿐만 아니라 학회, 협회에서 는 $\mathrm{CM}$ 이 어떠한 용역을 어떻게 수행하는지 구체적으로 기술 한 $\mathrm{CM}$ 표준업무 지침서를 작성하여 보유하고 있어야 한다.

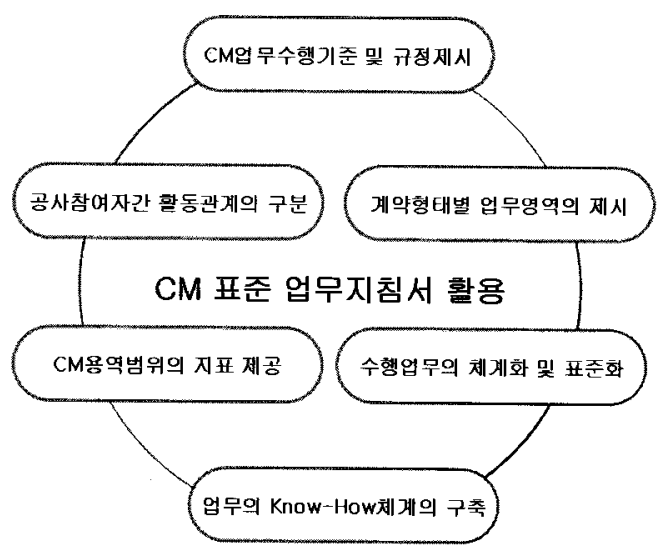

그림 3. $\mathrm{CM}$ 표준업무지침서의 활용
표준업무 지침서는 $\mathrm{CM}$ 용역의 상세한 업무기준, 과정, 절차 뿐만 아니라 $\mathrm{CM}$ 이 제공할 수 있는 용역을 열거한 일종의 매뉴 얼로서 전문건설관리를 수행하는 용역범위의 지표를 나타낸다.

대부분의 건설공사가 $\mathrm{CM}$ 이 수행할 수 있는 모든 용역을 필 요로 하지 않을 것이며, 반대로 멏몇 공사에서는 극히 전문적 인 용역을 요구할 것이다. 따라서 $\mathrm{CM}$ 표준업무지침서는 건설 사업 수행방식으로서 $\mathrm{CM}$ 이 제공할 수 있는 일반적이고도 전 문적인 모든 용역을 나타내야 한다. 단, $\mathrm{CM}$ 표준업무지침서는 $\mathrm{CM}$ 용역에 대한 매뉴얼이므로 범률적 강제조항, 의무조항, 제 한 사항을 두지 않아야 하며, 또한, 지침서상의 업무기준은 표 준계약서 $\mathrm{CM}$ 업무조항의 참조사항이므로 제약 조항과 직접적 인 계약관계를 갖지 않도록 작성되어야 한다. 표 20은 본 연구 에서 제안하는 $\mathrm{CM}$ 표준업무지침서 내용(안)이며, 이 자료는 그림 3과 같이 $\mathrm{CM}$ 업무수행기준 및 규정제시, 공사참여자간 활 동관계 구분, 수행업무의 체계화 및 표준화, 계야형태별 업무 영역의 제시, $\mathrm{CM}$ 용역범위의 지표제공, 업무의 Know-How체계 의 구축에 활용할 수 있다.

\section{5. 결 론}

본 연구는 미국의 $\mathrm{CM}$ 계약체계, $\mathrm{AIA}$ 및 $\mathrm{CMAA}$ 두 기관의 $\mathrm{CM}$ 표준계약서의 구성 및 역할 그리고 비교 분석을 수행한 후, 국내 $\mathrm{CM}$ 제도의 정착화를 위한 방안을 제시하고자 하였고, 그 결과는 다음과 같다.

첫째, $\mathrm{CM}$ 전문회사의 업무범위와 자격에 관한 규정을 설정 함으로써, 국내 $\mathrm{CM}$ 의 적극적 활용을 위해서는 발주자가 공신 력 있는 $\mathrm{CM}$ 용역을 의뢰할 수 있도록 공사 단계별 $\mathrm{CM}$ 의 업무 범위와 $\mathrm{CM}$ 업체의 자격조건을 조속히 제정해야 한다. 따라서 본 연구에서는 $\mathrm{AIA}$ 및 $\mathrm{CMAA}$ 두 기관에서 정의한 활동에 따 라 공사 단계별로 분석하여 국내실정에 맞는 $\mathrm{CM}$ 단계별 업무 범위 및 기술능력을 제안하였다.

둘째, 제정절차의 체계화로서 적격업체의 심사 및 선정, 계 약체결 등의 단계를 6단계로 구성된 $\mathrm{CM}$ 의 선정절차를 제시하 였다. 이에 고려되어야 할 사항은 $\mathrm{CM}$ 의 선정기준을 공사비 최 저가가 우선의 가격기준이 아닌 제안서 심사를 통한 능력기준 의 선정기준이 되어야 한다는 것이다.

셋째, $\mathrm{CM}$ 계약도서의 정비로 $\mathrm{CM}$ 방식뿐만 아니라 모든 사업 수행에는 계약자간 관계, 책임, 대가기준이 명시된 계약제도가 우선 정비되어야 한다. $\mathrm{CM}$ 표준계약서는 계약자간의 관계, 공 사 단계별 역할 및 책임, 대가기준 등이 명확히 명시되고 계약 자간 분쟁발생시 가능성을 최소화한 계약도서가 제정되어야 한다. 또한, 정부기관뿐만 아니라 관련협회와 학회에서 $\mathrm{CM}$ 계 약형태에 따른 각종 계약문서를 제정하여 당해 공사에 맞는 계 약문서를 취사선택할 수 있도록 하여야 한다.

넷째, $\mathrm{CM}$ 표준업무지침서 마련으로서 $\mathrm{CM}$ 의 기본적 업무와 기획, 설계, 입찰, 시공단계에서 수행할 $\mathrm{CM}$ 의 공사 단계별 업 무를 열거한 표준지침서 시안을 제안하였다. 
표 20. $\mathrm{CM}$ 표준업무지침서 제정(안)

\begin{tabular}{|c|c|c|c|c|}
\hline 기본업무 & 기획단계 & 설계단계 & 입찰단계 & 시공단계 \\
\hline $\begin{array}{l}\text { 1. 관리조직 구성 } \\
\text { 2. 관리요원 교육 } \\
\text { 3. 수행업무 법위 설정 } \\
\text { 4. 업무방향 구립 } \\
\text { 5. 정보교환체계수립 } \\
\text { 6. 업우절차의 정비 } \\
\text { 7. 각종 관리업무절차 수립 } \\
\text { 7.1 공사관리 } \\
7.2 \text { 일정관리 } \\
\text { 7.3 품질관리 } \\
\text { 7.4 안정관리 } \\
\text { 8. 관리조직내 업무일정 수립 } \\
\text { 9. MS 수립 } \\
\text { 10. 전산시스템 정비 } \\
\text { 11. 사용서식 및 기록도서정이 }\end{array}$ & $\begin{array}{l}\text { 1. 공사관리 } \\
1.1 \text { 발주자의 기획안 검토 } \\
1.2 \text { 경제적, 기술적 타당성 검토 } \\
1.3 \text { 공사범위 설점 } \\
1.4 \text { 공사관리 계획 } \\
1.5 \text { 공사관리 조직 } \\
1.6 \text { 공사 지침서 작성 } \\
1.7 \text { 공사정보보고체계 } \\
1.8 \text { 각종 문서처리 절차 } \\
1.9 \text { 분쟁, 클레임조정 절차 } \\
1.10 \text { 설계자 선점 맟 계약업무 } \\
1.11 \text { 공사대안 분석 } \\
1.12 \text { 품질관리 계획 } \\
1.13 \text { 부지구매 업무 } \\
2 . \text { 일점관리 } \\
2.1 \text { 계략공사일점 } \\
2.2 \text { 설계일정의 수정 갱신 } \\
2.3 \text { 입찰일정 } \\
3 . \text { 원가관리 } \\
3.1 \text { 예산확보 } \\
3.2 \text { 시장조사 및 경제예측 } \\
3.3 \text { 예산편성 } \\
3.4 \text { 개략견적 } \\
3.5 \text { 대안의 예산분석 }\end{array}$ & $\begin{array}{l}\text { 1. 공사관리 } \\
1.1 \text { 설계도서 및 시방서 검토 } \\
1.2 \text { 설계에 따른 시공성 검토 } \\
1.3 \text { 인허가 취득업무 } \\
1.4 \text { 공사대안분석적용 } \\
1.5 \text { 회의 개최 } \\
1.6 \text { 컨 팅 업무 } \\
1.7 \text { 공사계약조건수립 } \\
1.8 \text { 설계변겸 처리절차 } \\
1.9 \text { 설계기성관리 } \\
1.10 \text { 계약당사자간 업무조정 } \\
1.11 \text { 보증보험등록업무 } \\
1.12 \text { 자재, 장비조달계획 } \\
1.13 \text { 리스크분석 } \\
1.14 \text { 품질관리체계 시행 } \\
1.15 \text { 안전관리 } \\
1.16 \text { 단계별 시공시 절차확립 } \\
2 . \text { 일정관리 } \\
2.1 \text { 세부공사일정 } \\
2.2 \text { 설계일정의 수정 갱신 } \\
2.3 \text { 입찰일정 } \\
3 . \text { 원가관리 } \\
3.1 \text { 설계단계별 공사비 적산 } \\
3.2 \text { 생애주기비용 분석 } \\
3.3 \text { VE 적용, 대안비용 분석 } \\
3.4 \text { 예산통제 절차 }\end{array}$ & \begin{tabular}{l} 
1. 입찰 및 계약방법 \\
2. 관련업계현황조사 \\
3. $\mathrm{PQ}$ 기준설정 \\
4. 입찰공고 \\
5. 입찰문서 배포 및 발송 \\
6. 입찰설명회 \\
7. 입찰서 접수 \\
8. 입찰분석 \\
9. 입찰자 선정업무 \\
10. 시공계약업무 \\
11. 혐의(Negotiation) \\
12.자재공급자 및 잠비업자 \\
\multicolumn{1}{c}{ 선점 }
\end{tabular} & $\begin{array}{l}\text { 1. 공사관리 } \\
1.1 \text { 현장관리조직체계 } \\
1.2 \text { 계약당사자간 업무조정통제 } \\
1.3 \text { 현장회의 } \\
1.4 \text { 현장작업관리 } \\
1.5 \text { 시공도면, 시방서 검토 } \\
1.6 \text { 시공기성관리 } \\
1.7 \text { 공사변경 처리절차 } \\
1.8 \text { 발주자 업무보고체계 } \\
1.9 \text { 하도급관리 } \\
1.10 \text { 민원처리업무 } \\
1.11 \text { 인허가 취득업무 } \\
1.12 \text { 각종공사기록 } \\
1.13 \text { 시공자 보증보험등록 } \\
1,14 \text { 공사분잼해결업무 } \\
1.15 \text { 시공정보체계 } \\
1.16 \text { 자재구매관리 } \\
1.17 \text { 시공자 안전관리 이햄검토 } \\
1.18 \text { 기성 및 준공검사, 시운전 } \\
1.19 \text { 인수인계 } \\
1.20 \text { 품질검토 } \\
1.21 \text { 하자보수절차 } \\
2 . \text { 일정관리 } \\
2.1 \text { 시공일정관리 통제 } \\
2.2 \text { 시공일정 조정 갱신 } \\
2.3 \text { 공사변경에 따른 일정검토 } \\
3 . \text { 원가관리 } \\
3.1 \text { 공사비 일정 } \\
3.2 \text { 기성금 지급 } \\
3.3 \text { 대가지급청구서 처리절차 } \\
3.4 \text { 비용통제체계 } \\
3.5 \text { 비용관련 기록 }\end{array}$ \\
\hline
\end{tabular}

\section{감사의 글}

본 연구는 2007년도 서일대학 교내연구의 학술 연구비 지원 하에 이루어진 연구입니다.

\section{참 고 문 헌}

1. The American Institute of Architects, AIA Document B801/CMa Standard Form of Agreement Between Owner and Construction Manager(Where THE CM is CONSTRUCTOR), AIA 1992

2. The American Institute of Architects, AIA Document A121/CMa \& AGC Document 565 - Standard Form of Agreement Between Owner and Construction Manager(Where THE CM is CONSTRUC TOR), AIA 1991

3. The American Institute of Architects, AIA Document A131/CMc \& AGC Document 565 - Standard Form of Agreement Between Owner and Construction Manager(Where The Basis of Payment is The Cost of The Work Plus A Fee and there is no Guarantee of Cost), AIA 1994

4. The Construction Management Association of American, CMAA Document No A-1 - Standard Form of Agreement Between Owner and Construction Manager(Construction Manager as Owner's Agent), CMAA, 1993 